\title{
BOJ ZA ZNANJE V PRECEPU »BITI ALI IMETI«
}

rnila sem se iz. Kanade. Kako človek uživa, če spozna veliko novega in se veliko nauči.

$\checkmark$ Kanado se od časov svojega študija in specializacije po doktoratu vedno vračam kot $v$ domači kraj. In vendar se je Kanada od »mojih časov" do danes zelo spremenila. Prej.šnje družbeno-ekonomiske razsežnosti kanadske družbe (in drugih razvitih družb) so se po tridesetih letih pojavile tudi pri nas. Mi šele sedaj doživljamo potrošništvo, ki ga je Kanada preživljala v sedemdesetih letih ravnokar minulega stoletja. Nakupovanje je med glavnimi in najpopularnejšimi vrednotami našega usakdana. Trgovci iz družb, ki so to v precejšnji meri že prebolele, posku.šajo sedaj služiti na nas.

Obisk Univerze v Torontu, Univerze Guelph in Univerze Hamilton, pogovori s kolegi in opazovanje so mi dali upogled $v$ sedanjo razvojno stopnjo Kanade. Ob tem sem še bolj jasno zagledala našo realnost. Že Erik Fromm je v sedemdesetih letih napisal knjigo To have or to be. Lani je bila prevedena tudi v slovenščino: Biti ali imeti. Fromm je vizionarsko napovedal, kako se bo »družba imeti« prelevila $v$ »družbo biti«.

Na kratko bi lahko povzeli, da je naša družba pretežno na razvojni stopnji simeti« in da kanadska družba vedno bolj prehaja v naslednje razvojno obdobje - „bitik. Že pred nekaj desetletji smo sprejeli to Frommovo tezo, vendar nismo imeli jasnejšega odgovora, kako se bo
LIVODNIK

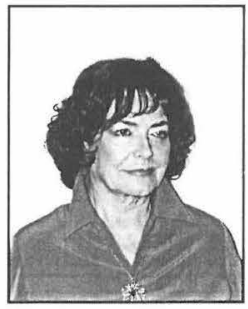

to zgodilo. Nove razsežnosti kanadske drǔbe že v veliki meri odkrivajo te poti. Morda bi se učili od njih in laže predvidevali prihodnost.

$V$ zadnjih desetletjih se pojavlja pri ljudeh premik $v$ temeljnih vrednotah. Če jim je nekoč ideal pomenila enodružinska hiša z urrom $v$ urejeni soseski mesta, se jim ta zdi danes breme. Za starejše ljudi je hišsa predrag način bivanja, mlajši pa menijo, da bi jim hiša in vrt vzela preveč časa, ki ga nujno potrebujejo za iskanje informacij, učenje in prilagajanje spremembam. Pomembneje se jim zdi, da so prek računalnika neprestano povezani s svetom, da si sproti zagotovijo potrebno znanje in da ne zaostajajo z informacijami. Zato cenijo novo obliko bivanja: elegantna stanovanja v. visokih nebotičnikih (imenujejo jih scondominion «). Hiše izgubljajo na ceni in nekatere soseske enodružinskih hi.š izgledajo prav zapuščene in revne. Stanovanja v nebotičnikih so vsa razprodana, še preden so zgrajena. Življenje v stanovanjih je manj obremenjujo$\breve{c e}$, ker za vse poskrbijo ustrezne službe (vratar, vrtnar, varnostnik, snažilka, cvetličarka, tehnični vzdrževalec itd.). Ljudje živijo kot v hotelu. Tudi gospodinjskim delom se ne posvečajo, ker imajo v neposredni soseski na razpolago razne servise (pripravljeno hrano, čistilnice, pralnice itd.). V elegantnih četrtih stanovanjskih nebotičnikov trgovine niso zaželene. Gradijo jih v podzemmih ulicah ali jih skrijejo za fasade z zatennjenimi stekli. V tch krogih se potrošništvo ne ceni, ker ljudje posvečajo večino svoje pozornosti sposobnosti in moči za ohranjanje osebne kompetentnosti 
in čin šrš̌e zaposljivosti. Ker jim oboje neprestano polzi skozi prste in zastareva, znanie neprestano dopolninjejo in razrijajo nove sposobnosti. Delo in izobrẵevanje se prepletata in gresta z roko v roki. Živijo v mešanici tekme za znanjem in delom.

$V$ pcondominionih « Živ elita najbolj osveščenih, izobraženih in za rizloj zanzetih ljudi. $T a$ sloj liudi se bori za znanje, zato da so na tekočen z informacijani; pomembno jim je sbitia in he »imeti《. Skrbi jih, kaj zmorejo, to jim daje občutek warnosti, in ne to, kaj imajo.

Potrošnišstu cueti med nižjim slojem. Še vedno je hiša vrednota, pa čeprav malo slabše vadrăevana. Skrbi z vrtom, zelenico in u'sem, kark hiš spada, jim vzamejo veliko časa. $\mathrm{Na}$ razpolago so jim razni centri za ceneno zabaro, igre za driganje adrenalina, razni mlanaparki«, hiše grozot in kupi cenenega blaga za poceni prodajo. Večinoma je naprodaj kitajsko blago. Cene se urtijo okrog dolarja. Trgovin je veliko. Lahko so nemarne in bolj podobne skladišcem kot pa trgorinam, samo da se kupuje. Potrošniki se upehajo od vriljakos, toboganov in hrupa, upehajo se sredi nakupov. Kratek počitek, malo posedijo na tleh sredi masownih trgovin in spet hitijo naprej in naprej: zabave in nakupi. Osrečuje jih to, da imajo. Ne sprašujejo se o kakovosti, dizajnu in ali nakupljeno robo sploh potrebujejo. Sebe prezrejo voplavi hrtpnih zabav in cenenih trgovskih artiklow. Imeti, imeti.

Ljudje, ki ne morejo slediti razroju in iti korak s spremembami, se oprijemajo starih vrednot potrošnišstva. Č utijo, da zaostajajo za naprednejsimi, zato jih napadajo strahovi. Premagujejo jih $z$ adrenalinskimi zabavami. Manj so zaposljivi in čas jim ostaja, da ne vedo, kam z njim.

Nasprotno gre življenje $v$ 'išjem socialnem sloju naprej $z$ veliko naglico in je napeto, zahtevno. Sroj višji položaj morajo ti ljudje ne- prestano braniti in se truditi, da ga ohranijo. Družba ni več piramida z višsimi in nižjimi družbenimi sloji. Je vrtinec: Ljudje "r stiki tega dražbenega urtinca živijo pod najuečjimi pritiski. Če se ne borijo za znanje, informacije, ce ne obnarljajo svojih kompetenc in zaposljivosti, jih hitro odnese na rob družbe. $V$ informacijski družbi družbeni položaj ni več nekaj fiksnega in trajnega, kot je bil nekox. Ljadje prihajajo na položaje in jih izgubliajo. Boj za ohranitev najuišjih položajev je neizprosen. V nižjem socialnem sloju, ki se napaja p simeti«, so pogosto tudi priseljenci. Prišli so iz dežel. kjer je ponanjkanje, nova domovina jim pomeni predusem materialno blagostanje. Osrečuje jih možnost, da si lahko privoǚ̈ijo materialne dobrine, ceprat so na robu drǔ̌be.

$\checkmark$ današnji kanadski aružbi opazimo dva izrazita vrednostna sistema, dve podobi družbe: zgomji in spodnji družbeni sloj. ostanke prejšnje industrijske družbe in prevladovanje nove informacijske družbe. Na star način, ss starimi vrednotami in stališč vapon 1 novi družbi ni več moミ̌en. Ljudje uspejo, če znajo zaziveti na nov, posvetijo swoj čas ačenja in zhanju, skrbijo za swoje duhowno stanje, postajajo odporni na stres in so samostojni ter polno odgovorni za to, kar počno, prilagodljivi in sposobni za sodelovanje in dialog. Od kompetentnih prihajajo v zgornji družbeni sloj še kompetentnejšsi in najkompetentnejši. $V$ spodnjem sloju so obstali v suojem poklicu, prepočasi se razbijajo in napredujejo. C̆as jih pušča za seboj.

Kanada ima že nekaj desetletij ̌̌olski sistem, s katerim usem nuladim odpira pot wšsudij naterciarni ravni (posrednješolski nivo). Vsi otroci gredo po osnowni šoli, ki traja pribtižno toliko kot naša, v gimnazijo (angl. high school). Izbirni predmeti gimnazijskega programa omogočajo, da se izrazijo posebni talenti in razlike med otroki. Mladina po gimnaziji 
nadaljuje studij na višjih solah in aniverzah zelo različnih wrst. Lahko se odločijo za krajši studij na mobčinskih kolidžih ali pa se vpišjo na razne daljše univerzitetne programe. Praviloma naj bi po splošni srednji soli vsak miad člowek nadaljeval študij. Nekatere najzahtevnejše univerze pogojujejo vpis z najvišjimi ocenami iz gimnazije, druge univerze (npr. Simon Frazer univerza) inajo prost dosiop do šndija. Podoben trend mino konzervativne politike nastaja tudi y naši praksi: mladina navaljuje na gimnazije, te se najhitreje šrijo, madi pa se upirajo, da bi šli v due-ali triletne poklicne šle, ker vedo, da je za življenje $v$ družbi znanja in za vseživljenjsko izobraževianje to premalo. Med ljudmi vlada mnenje, da smora vsak mlad človek še nekaj šsudirati, ker dragače ne bo zaposljiv, ne bo dobil delar.

Kanada je prepredena s terciarnim izobraževanjem: $z$ višjimi in visokimi šolami ter univerzami. Univerze iz manjšsh krajev imajo dislocirane enote v vecjih mestih. Prostorsko so se naselile v neboričnike v strogen centru mest. Śnadij je zelo osebno prikrojen, ker ga odrasil kombinirajo z delon in družino. S̆ dentje izbirajo med visokošolskimi ustanovami glede na to, kje se bodo več naučili, kje jim obetajo večji osebni razvoj.

Drugo, "čemer se odlikuje kanadska družba, je razvit in tradicionalen sistem izobraževanja odrastih. Poleg izobraževanja iz oči y oct se med odraslimi siri znanje prek posebnih 24-urnih televizijskih progranov, nove tehnologije in satelifa, prek katerega teče študij na daljavo. Mestne čtrti imajo tako imenovane skupnostne centre odprtih vrat (angl. community cemers) za srečanja ljudi, učenje, druženje in kulturo. $V$ določeni četrti mesta, navadno ob parkih in sprehajališcih, so zgošcene razne umetnostne delavnice. Pri starejsih delavih je visja ali visoka izobrazba manj zastopana kot pri mladih. Zato si na razne načine prizadevajo, da si jo pridobijo.
Niso redki primeri, da si odrasli pridobijo po dia ali tri magisterije v različnih strokah, da bi bili kompetentnejši in bolj zaposljivi. Pogost motiv za izobraževanje je pri odraslih adi saseben nagib, uživanje pri odkrivanju novega in učenju". Ko bolj od blizu pogledamo vesplošno izobraževanje odraslih, navadno opazimo, da ni tako slučajno, da ima usak človek nek načrt, kaj bo s tem novim znanjem počel in zakaj se uči prav to in ne kaj arugega. Sietovalci in mentorji pomagajo ljudem do astreznega osebnega izobraževalnega nacria. Učenje je vedno kombinacija različnih pori do znanja in različnih programow. Izbor je zelo oseben.

Večina večjih mest ima tako imenovan center znanosti (angl. science center). Velike in razvejane zgradbe ponujajo obiskovalcem, da spoznalajo znanosti na nazoren in dostopen način. V enem takih centrov znanosti (Sadberry') smo vstopili $v$ delavnico, kjer je nekdo razlagal Newtonove zakone prek primerov iz prakličnega življenja in v okviru gradije vesoljskih raket. Med publiko so bili zelo mali predšolski otroci in odrasli tja do 80 let. $V$ taken centru ti mimogrede mine dan, pa si si ogledal le nekaj delčkov tega, kar center ponuja. Skoraj ne pomisliš, da si se ves dan učil. Prijetno je bilo, le časa zmanjkuje. Znanost ni elima, širi se med ljudi med drugin tudi prek računalniške tehnologije: $C D-R O M o v, M P 3$ in UBS.

$V$ učeči se družbi Kanade imajo pomembno vlogo knjige in knjižnice. Knjige so popularnejše bolj kot kadarkoli prej. Jemljejo jih kot potrošno blago. Ko knjigo preberejo, jo dajo naprej ali odvržejo. Knjige so dostopne po zelo nizkil cenah, ker so naklade $v$ angleščini velike. Nove knjige dobijo po znižanih cenah $\checkmark$ posebnih knjigarnah, kanor založniki pošljejo svoje viške od prodaje. Še bolj poceni so v knjižnih starinamicah. V rednih knjigamah ljudje čakajo, da knjiga izide še v broširani 
(cenejši) izdaji. Knjige za vak cent dobite pomešane v trgovinah z rabljeno robo. Nekaterim se ne zdi ponembno, da bi jih ločevali, in jih prodajajo skupaj z rabljenim pohistvom in oblekami. S̆revilo knjižnic se širi. Osrednja knjižnica, npr. v Vancouvru, je arhitekturno izstopajoča mogočna in osrednja mestna zgradba. Bralcem ponuja intinue ambiente za branje in raznišljanje. Vsak obiskovalec si lahko po svoje uredi, kje bo bral, se učll. $V$ mestih so rudi knjižnice y posanteznih soseskah in specializirane knjižnice. Poleg knjig vključajejo tudi vsa sodobna digitalna sredsiva za učenje.

Ko sem bila članica mednarodne delegacije za izobraževanje odraslih na Kitajskem, so nam domačini razložili, da tako kot človek tudi družba potrebuje dve nogi, da hodi naprej: ena noga je šlski sisfem in druga izobraževanje odraslih. Nobena ne sme manjkati. Težko bi rekli, kaj je v Kanadi bolj razvito: šolski sistem ali izobraževanje odraslih.

Že par desesletij v Kanadi narašča število svetovalnih služb ali "zhanje na posodo«. Zgodi se, da je čas med tem, ko človek naleti na nek problem, in rokom, ko se je treba odločiti za rešitev probiena, prekratek, da bi se človek sam usposobil za kompetentno reševanje. Takrat mu ne preostane drugega kot "znanje na posodo". Zateče se h kompetentnim strokovnjakom v suetovalne službe in se zanese na njihovo znanje in sposobnosti. Svetovalne službe delujejo za isa področja in so prostorsko večinoma tam, kjer so knjižnice, knjigarne, univerze in druge ponudbe znanja, $v$ samih centrih mest.

Neprimerno pomenbnejšo vlogo kot pri nas imajo društva in druge civilne družbene organizacije. Društvo za neodvisne medije in objektivno posredovanje informacij sodeluje neposredno z vlado Ontaria in zvezno vlado v Otawi. Podobno delujeta tudi društvo za odprt dostop do šolanja in društıo za boj proti diskriminaciji. Drušnva bohnikov in prijateljev ljudi prizadetih z določeno boleznijo poskrbijo za kakovostno hospitalizacijo bolnikov in pobolnišnično zivljenje prizadetih oseb. Zdravniki in klinike se zelo zanašajo na ta društva pri zagotavljanju kakovosti zdravljenja. Brez njih ne bi mogli, trdijo zdravniki. Ozaveščanje in informiranje pacientov je pretežno v rokah društev. Ljudje se zancišajo nase in ne čakajo, da vasako stvar reši država. Delujejo bolj samostojno in načrtno. Soseska potrebuje društveni c'enter. Skupina ljudi sestavi načrt za pridobivanje sponzorjev, za pridobitev z gradbe, vsebino centra itd. Ljudje ne gledajo le nase, zelo pomembno jim je tudi splošno dobro, saj sam človek ne more preživeti, vedno je odvisen od skupnosti.

$V$ Kanadi se že soočajo z uresničitvijo informacijske družbe ali učeče se družbe. Medtem ko inamo pri nas še vse bolj na rawni idej in sprejetih načel, nastajajočih konceptov in političnih fraz, je to v kanadski družbi v zadnjih treh desetletjih (od izida knjige A. Tofflerja Future shock dalje) že postalo del prakse. Izobraževanje odrasith, ko bi ga najbolj rabili, ukinjamo, šlski sistem je izločevalen in selekcijski, izloča že mlade, čeprav je v sodobni družbi znanje kot zrak, ki ga vsi dihamo. Kako naj kdo preživi brez zraka? Množica odvisnežev od drăave se veča, istočasno pa se gospodarstvo pritožluje nad dajatvami za socialne programe. Zakaj probleme se naprej sami ustvarjamo? Kam z mladimi brez srednjih šol ali brez višješolske izobrazbe? Kam z aktiwnim delom prebivalstua brez sol? Kanadska družba je lep primer, kako gre pot uresničevanja učeče se družbe.

Dr. Ana Krajnc

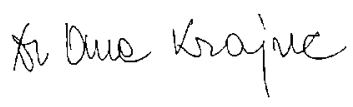

